Running head: BROADENING FOREIGN MARKET ENTRY MODE DECISION

\title{
BROADENING THE FOREIGN MARKET ENTRY MODE DECISION: SEPARATING OWNERSHIP AND CONTROL
}

James R Brown ${ }^{1}$

Chekitan S. Dev²

Kevin Zheng Zhou ${ }^{3}$

December 2, 2002

${ }^{1}$ Department of Marketing, Pamplin College of Business, Virginia Tech, Blacksburg, USA

${ }^{2}$ School of Hotel Administration, Cornell University, Ithaca, NY, USA

${ }^{3}$ School of Business, University of Hong Kong, Pokfulam, P.R. China

Correspondence to:

Professor James R Brown, Department of Marketing (0236)

Pamplin College of Business, Virginia Tech,

Blacksburg, VA 24061

Tel: +1 5402317247

Fax: + 1 540-231-3076

E-mail: jamesb@vt.edu 


\title{
BROADENING THE FOREIGN MARKET ENTRY MODE DECISION: SEPARATING OWNERSHIP AND CONTROL
}

\begin{abstract}
This paper argues that the ownership and control dimensions of foreign market entry mode choice should be separated, and that foreign market entry mode decisions should be expanded to business activities beyond production and distribution. Empirical results from the global hotel industry indicate that the transferability of the entrant's competitive advantages, the local market's absorptive capacity, and the availability of trustworthy local partners differentially affect the ownership and control dimensions of the entry mode decision.
\end{abstract}

Keywords: foreign market entry; competitive advantages; ownership; control 


\section{INTRODUCTION}

The choice of foreign market entry modes has been a topic of considerable inquiry in the international business literature (for reviews see Andersen, 1997; Luo, 1999). The primary objective of these studies is to uncover the factors that determine the modes used to enter foreign markets. The key assumption underlying this literature is that the best entry mode is one that aligns the entrant's strengths and weaknesses with the local market’s environment as well as with the firm's structural and strategic characteristics (e.g., Hill et al., 1990; Ekeledo and Sivakumar, 1998).

‘[Foreign market e]ntry mode has been defined as an institutional arrangement for organizing and conducting international business transactions...' (Andersen, 1997, 29). In their hierarchical model of market entry modes, Pan and Tse (2000) argue that the choice of foreign market entry modes involves two steps. First, entrants decide whether to make an equity investment in the foreign market. Next, within the equity or non-equity choice, entrants select the specific entry mode (e.g., indirect exporting, licensing, franchising, joint venture, wholly owned subsidiary). Although the ownership dimension and the control dimension of foreign market entry mode choice are strongly correlated (Anderson and Gatignon, 1986; Keegan, 2002), the key insight of the Pan and Tse (2000) model is that these dimensions can be separated.

We extend that insight by arguing that not only can the ownership and control dimensions be split, but the foreign market entry mode decision must also be made for each business activity that the entrant undertakes on behalf of the foreign market. Previous research on the foreign market entry mode decision, however, has centered on the production and distribution functions (Buckley and Casson, 1998). But in the service industry, which makes up 20-25\% of the total world trade and is growing by $20-30 \%$ annually (Ekeledo and Sivakumar, 1998), firms view foreign market entry in terms of a variety of business activities, not just production and distribution. For this reason, we explicitly study the separate entry mode choices for two key business activities: investment in local market physical facilities, and control over local market operations and marketing. Thus we contribute to the literature by broadening the concept of foreign market entry to include business activities beyond production and distribution. 
Recently, researchers have identified a number of strategic factors that may impact entry mode decisions from a competitive advantage perspective. For example, Bradley and Gannon (2000) examined how a firm's market concentration/ diversification strategy influences its choice of foreign market entry mode. Kim and Hwang (1992) studied how global concentration, global synergies, and global strategic motivations affect the choice of foreign market entry mode. Contractor and Kundu (1998a) investigated how various strategic factors (the importance of scale economies, quality control, reservations systems, need for size, and investment in training) influence a hotel firm's foreign market entry mode selection. Erramilli et al. (2002) studied how a firm’s imperfectly imitable capabilities affect its choice of nonequity foreign market entry modes (franchising vs. management- service contracts).

According to the resource-based view, a firm's competitive advantage is rooted in its own resources and those that it can acquire (Wernerfelt, 1984; Barney, 1986, 1991; Conner, 1991). One key resource is the firm's knowledge, more specifically, its codified knowledge (i.e., knowledge that can be easily identified, structured, and communicated) and its tacit knowledge (i.e., knowledge that is rooted in the firm’s culture, routines and processes) (Kogut and Zander, 1992; Madhok, 1997). In this paper we investigate how a firm's competitive advantage rooted in its tacit and codified knowledge affects its choice of foreign market entry mode. Hence we extend the extant literature by examining specific yet generalizable aspects of competitive advantage in studying foreign market entry mode.

This paper is organized as follows. First, we describe our expanded conceptualization of foreign market entry modes. Second, we develop hypotheses that show how the choice of foreign market entry modes varies according to the ease with which a firm can transfer its competitive advantages to the local market. Next, we describe the empirical study and the analytical tools used to test the hypotheses. The results of our study are then presented, followed by a discussion of their implications for managers and researchers. Finally, we conclude with an assessment of the contributions of our research. 


\section{BROADENING THE FOREIGN MARKET ENTRY MODE DECISION}

According to the resource-based view, a firm possesses a set of resources (such as financial capital, physical assets, and know-how) that it uses to deliver customer value, achieve competitive advantage, and earn satisfactory returns for its shareholders (Conner, 1991; Bharadwaj et al., 1993; Conner and Prahalad, 1996). For firms seeking to enter foreign markets, a critical issue is whether they can apply their competitive advantages to those markets.

Their success in local markets depends heavily on their ability to transfer their know-how to the local market, as well as on the ability of the local partner to absorb that know-how (Madhok, 1997). Not all potential foreign market entrants possess sufficient knowledge of the local market to earn acceptable returns on their resources; nor are they able to develop that knowledge in a timely or cost-effective manner (Madhok, 1997). However, by collaborating with local partners, a firm entering a foreign market can fill gaps in its knowledge base (Erramilli and Rao, 1990; Aulakh and Kotabe, 1997; Burgel and Murray, 2000; Luo, 2001). By collaborating with entrants, local partners can gain access to the entrant's know-how. This mutual association enables both firms to increase the likelihood of earning greater returns on their resources.

The entrant will realize greater returns from such collaborations to the extent that its know-how can be readily transferred to the local partner and the local partner can absorb that know-how (Madhok, 1997). Absent these conditions, the entrant will attempt to wield more control in the local market. Greater returns can be jeopardized if dealing with the local partner raises transaction costs - the costs of designing, negotiating, executing, and monitoring exchange transactions (Teece, 1980; Hill et al., 1990; Erramilli and Rao, 1993). Essentially, transaction costs are higher when the value of the firm’s resources and capabilities is at risk. This can happen when entrants have little experience with or knowledge about the local markets, or their local partners (Kim and Hwang, 1992). The more these conditions exist, the more vulnerable the entrant is to local partner opportunism; hence the more likely it is that the entrant will use ownership to protect itself in local markets (Hill et al., 1990; Andersen, 1997). 
According to the resource-based view, entrant firms choose entry modes to capitalize on the local partners’ capabilities (Andersen, 1997; Madhok, 1997) and, according to transaction cost analysis, to protect themselves from potential opportunistic behavior (Teece, 1980; Hill et al., 1990; Erramilli and Rao, 1993). Foreign market entry modes have typically been arrayed according to levels of control (Anderson and Gatignon, 1986; Erramilli and Rao, 1993; Ekeledo and Sivakumar, 1998; Pan and Tse, 2000), extent of ownership and resource commitment (Erramilli and Rao, 1993; Luo, 1999; Pan and Tse, 2000), and degree of risk (Hill et al., 1990; Luo, 1999). Although these dimensions have been viewed as highly interrelated (Keegan, 2002), Pan and Tse's (2000) research suggests that the ownership and control dimensions of the foreign market entry mode decision can be separated.

Historically, local partner expertise has been viewed solely in terms of production, distribution, and R\&D (e.g., Buckley and Casson, 1998). Because economic, technological, and competitive pressures have motivated many firms to specialize in those activities in which they possess (or can readily gain) a competitive advantage (Stern et al., 1989; Achrol, 1997; Walker, 1997), they outsource the remainder of their business functions to partners who possess complementary resources, skills, and expertise to leverage their competitive advantages (Achrol, 1997; Walker, 1997). And those complementary resources, skills, and expertise increasingly extend beyond production and distribution.

Figure 1 shows various business functions that can be undertaken when a firm enters a foreign market. Some (such as R\&D, plant and equipment, marketing) may entail higher risks of local partner opportunism; some (such as plant and equipment, distribution) can be easier to transfer to local partners. Within a particular function (e.g., marketing), the entrant should undertake some activities (such as branding), whereas the local partner can more easily perform others (such as pricing). Hence foreign market entrants must decide which functions can be transferred to local partners, which require more entrant control, and which necessitate entrant ownership.

This separation of ownership and control can characterize any industry, but it frequently occurs in service industries (Erramilli et al., 2002). Local investors without industry expertise often purchase land and build facilities for the service firm to manage (e.g., in the restaurant and hotel industries). Or the 
service firm can finance the purchase and construction of its own physical facilities. The service firm can also develop its own policies and procedures for controlling local marketing and operations.

Alternatively, the service firm can rely upon the expertise of a franchise system or marketing network to guide its local marketing and operations. Table 1 illustrates these two dimensions in the context of the global hotel industry, the empirical setting that we use in this research.

The vertical dimension of Table 1 distinguishes foreign market entrants that have an ownership stake in the local hotel from those that do not. The horizontal dimension of Table 1 categorizes local hotels according to whether their marketing and operations activities are shaped by franchise system or third-party marketing network policies and procedures, or whether they are determined by the entrant's company policy. Chain-owned, affiliated hotels (COA) are operated as part of a franchise system (e.g., Holiday Inn) or a marketing network (e.g., Utell, Leading Hotels of the World). The market entrant invests in the physical assets of these hotels, but relies (at least partially) upon the franchise system or marketing network for its operating and marketing policies and procedures. Management company, affiliated (MCA) hotels are operated by a third-party management company and are also linked with a franchise system or a marketing network; however, the entrant does not hold an equity position in the hotel. MCA hotels are also subject to the dictates of the franchise system or marketing network. Management company, unaffiliated hotels (MCU) are operated under management contract but are not affiliated with either a franchise system or a marketing network. The policies and procedures governing the marketing and operations of these hotels are developed in-house, rather than by a franchise system or marketing network. Chain-owned, unaffiliated (COU) hotels are owned and operated under a common brand name as part of a corporate chain, but are independent of either a third-party management company or franchise system. Thus the COU mode offers the entrant the highest level of control over the hotel's marketing and operations. 


\section{THE HYPOTHESES}

Our earlier discussion of resource-based and transaction cost perspectives suggests that three important factors - the entrant's ability to transfer its know-how to the local market, the local partner's ability to absorb that know-how, and the availability of qualified and trustworthy local partners - impact the choice of foreign market entry mode.

\section{Ability of entrant to transfer know-how}

As noted earlier, the choice of foreign market entry mode depends on the mode's ability to transfer the parent company's competitive advantages. These competitive advantages in service industries, such as the hotel industry, are rooted, in part, in the firm's knowledge base (Bharadwaj et al., 1993). Knowledge that is more easily identified, structured, and communicated is termed codified knowledge (Kogut and Zander, 1992). Codified knowledge in service industries includes standard products (service offerings), standard operating procedures, standard training programs, and uniform physical facilities. Because it is standardized, codified knowledge can be transferred more easily to a foreign partner.

In contrast, tacit or embedded knowledge is more difficult to transfer because its effectiveness relies upon the firm's individual employee skills and experience as well as its organizational routines and processes, which are reflective of its unique organizational culture (Cohen and Levinthal, 1990; Kogut and Zander, 1992; Madhok, 1997). Examples of tacit knowledge include consumer complaint-handling processes, organizational dedication to providing service quality, and unique ways of adapting to changes in the demand, competitive, and technological environments.

In this research we investigate three important types of competitive advantage that market entrants in the hotel industry can possess. Ability to generate customer service and superior company management and organization are indicative of the market entrant's tacit knowledge base (Erramilli et al., 2002). Distinctive and effective physical facilities exemplify the market entrant's codified knowledge base. These three facets of competitive advantage were chosen because they represent both tacit and 
codified knowledge. In addition, they are critical to the success of service businesses such as hotels (Bharadwaj et al., 1993).

Generating customer service refers to the ability to create and maintain a sufficient customer base and to ensure customer satisfaction. Such a customer orientation is a critical determinant of firm performance (Narver and Slater, 1990). Knowledge about how to generate customer service is difficult to codify, and hence is tacit. Because tacit knowledge cannot be easily organized or understood, it requires a high level of managerial, human, and financial resources to be transferred adequately to foreign markets (Bello and Gilliland, 1997). Firms investing in such resources will also require sufficient control to ensure that foreign partners will not behave opportunistically (e.g., by shirking), so as to undermine that competitive advantage (Kim and Hwang, 1992; Contractor and Kundu, 1998a). For these reasons, we believe that firms that have a competitive advantage in generating customer service will use entry modes affording higher levels of control over the hotel's marketing activities (to build customer expectations) and operations (to fulfill those expectations). The entrant's customer service competitive advantage has little bearing upon the ownership dimension of foreign market entry mode because ownership pertains to physical facility, not customer service. Hence we hypothesize that:

Hypothesis 1: The greater the competitive advantage of the market entrant in generating customer service, the more likely it is to use foreign market entry modes characterized by higher levels of control over marketing and operations (i.e., COU > COA; MCU > MCA).

Superior company management and organization refers to the competitive advantages emanating from the firm's managerial and organizational knowledge and skills. Effective and efficient management and organization provide the basis for satisfying the firm's target market needs and wants, as well as enabling the company to achieve cost leadership (Day and Wensley, 1988). The management and organization competitive advantage is difficult to duplicate because it is based upon tacit knowledge, which includes underlying management skills as well as decision heuristics involved in identifying and solving operational problems (Polanyi, 1966; Cohen and Levinthal, 1990). It also includes written rules 
and procedures, which are difficult to transfer without a complete understanding of the context in which they were developed. Another aspect of the management and organization competitive advantage is the firm's management information system. This know-how is difficult to transfer (Teece, 1980) and requires periodic updating due to rapid technological innovation. Thus the management and organization competitive advantage is difficult to transfer to the entrant's local market without a large commitment of managerial, human, and financial resources. And that commitment requires more control to ensure that those resources are being used properly (Luo, 1999). Because they must follow the policies and procedures of the franchise system or marketing network, affiliated entrants have less control and are therefore constrained in their ability to transfer their management and organization competitive advantage. Competitive advantage based upon superior company management and organization has no bearing upon the ownership of local physical facilities. Hence we hypothesize that:

Hypothesis 2: The greater the market entrant's management and organization competitive advantage, the more likely it is to use foreign market entry modes characterized by higher levels of control (i.e., $\mathrm{COU}>\mathrm{COA}$; $\mathrm{MCU}>\mathrm{MCA}$ ).

In the lodging industry, physical facilities such as the decor and design of a property are tangible signals of the intangible lodging experiences that hotels provide to their customers. The knowledge of how to construct quality physical facilities and decorate them accordingly can be codified and communicated without much difficulty to the entrant's local market partner. In addition, high costs preclude hotels from changing their physical facilities frequently. As a result, hotel companies are unlikely to transfer continuously their physical facilities know-how. Thus, because it can be codified and is relatively constant and tangible, the entrant's competitive advantage in terms of physical facilities can be readily transferred to its local market partner. This allows the entrant to avoid the financial and managerial resource commitments resulting from ownership (Conner and Prahalad, 1996).

Although codified knowledge about the entrant's physical facilities can be readily transferred, local owners of the physical facilities may not acquiesce to the entrant's desires. Quite simply, their 
ownership of those physical facilities provides them with the final authority over the design and decor of the hotel property. If the local owners do not abide by the entrant's guidelines, the entrant may not be able to fully capitalize on its physical facilities competitive advantage. Hence there is no guarantee that this competitive advantage will be transferred to a foreign market. For this reason, we expect the entrant to invest in the local operation when its codifiable knowledge involves physical facilities. Because this source of competitive advantage does not pertain to marketing or operations, the entrant can accept a lower level of control over those business activities.

In summary, we posit that:

Hypothesis 3: The greater the market entrant's competitive advantages in terms of physical facilities, the more likely it is to use foreign market entry modes characterized by equity ownership (i.e., COA > MCA; COU > MCU) and lower levels of control over marketing and operations (i.e., $\mathrm{COA}>\mathrm{COU}$; $\mathrm{MCA}>\mathrm{MCU}$ ).

\section{Ability of local partner to absorb the entrant's know-how}

The choice of foreign market entry mode also hinges upon the ability of the local partners to absorb and utilize that know-how to the entrant's advantage (Madhok, 1997; Contractor and Kundu, 1998a). One critical factor that determines a firm’s absorptive capacity is its related knowledge (Cohen and Levinthal, 1990). In a foreign market, the local partner's related knowledge depends heavily upon the local market availability of qualified labor, talented management, and reliable suppliers, as well as the costs of training local labor and management.

Resource availability refers to the local availability of qualified service employees, managerial talent, and reliable suppliers. The more the local market can provide these important resources, the more the parent company can utilize low control entry modes (Anderson and Gatignon, 1986). First, the parent firm's knowledge and skills can be more easily transferred to markets where required personnel, managerial, and supply resources are plentiful (Contractor and Kundu, 1998a, 339). And, second, the availability of such resources (i.e., a competitive environment) quashes any opportunistic tendencies of 
the local partners. This is not the case where resources are scarce, where entrants either supply their own resources, or where they throw themselves at the mercy of an opportunistic monopolist. Hence, where local resources are plentiful, the entrant can relinquish control over marketing and operations without the firm being adversely affected. Local resource availability does not influence the ownership of the local operation's physical resources, however. For these reasons, we expect that:

Hypothesis 4: The more available the resources in the local market, the more likely it is that the firm will use foreign market entry modes characterized by lower levels of control over marketing and operations (i.e., $\mathrm{COA}>\mathrm{COU}$; MCA > MCU).

Training costs refers to the costs of training local service employees and local managerial staff. High training costs make it difficult for the parent firm to transfer its knowledge and skills to the local market (Bello and Gilliland, 1997). Such difficulties favor foreign market entry modes characterized by higher levels of control (Contractor and Kundu, 1998a). Moreover, high training costs imply that qualified human and managerial resources are scarce, thereby making the entrant vulnerable to local market opportunism (Contractor and Kundu, 1998a). Hence, consistent with our reasoning for H4, resource scarcity leads the market entrant to use higher control modes of foreign market entry. Because training costs are independent of the local market's physical facilities, the ownership dimension of foreign market entry mode is not affected. In sum, we predict that:

Hypothesis 5: The higher the training costs in the local market, the more likely it is that the market entrant will use foreign market entry modes characterized by higher levels of control over operations and marketing (i.e., COU > COA; MCU > MCA).

\section{Availability of qualified and trustworthy local partners}

Another important factor in selecting a foreign market entry mode is the availability of local investment partners. The lack of qualified and trustworthy investment partners precludes the market entrant from using local partners to acquire the land and build the physical facility. Hence the entrant 
must invest in the local market's physical resources. Further, if the entrant decides to use unqualified or untrustworthy local partners, the firm may be vulnerable to opportunism by those local partners. However, when the local market is able to provide trustworthy and qualified investment partners, the entrant can utilize entry modes that require lower levels of equity participation (Anderson and Gatignon, 1986; Luo, 1999). Decisions about the entrant's extent of local control over marketing and operations are made independently of the availability of local investment partners. Hence the ownership dimension is the only aspect of the entry mode decision affected by the availability of local investment partners. Therefore we believe that:

Hypothesis 6: The greater the availability of local investors, the more likely it is that the market entrant will eschew foreign market entry modes characterized by equity ownership (i.e., MCA > $\mathrm{COA}$; MCU > COU).

\section{Control variables}

A number of other factors affect a firm's choice of foreign market entry mode (Luo, 1999).We offer no formal hypotheses for these factors, but we do control for them in the empirical analysis. For example, the local market's potential in terms of its current size and potential for growth has been found to influence foreign market entry mode (Contractor and Kundu, 1998a; Ekeledo and Sivakumar, 1998; Olsen et al., 1998; Gatignon et al., 1990; Luo, 1999). The local market’s general business conditions, such as the quality of its infrastructure, its general business conditions, and its political stability, have also been found to affect foreign market entry mode (Hill et al., 1990; Contractor and Kundu, 1998a, b; Luo, 1999; Erramilli et al., 2002). Sociocultural distance - differences between the market entrant's home country and the local market in terms of business practices and norms as well as social culture (Hill et al., 1990) is another important factor (e.g., Anderson and Coughlan, 1987; Hill et al., 1990; Erramilli and Rao, 1993; Bello and Gilliland, 1997; Contractor and Kundu, 1998a, b). Still another is firm size (e.g., Dunning and McQueen, 1981; Erramilli and Rao, 1993; Contractor and Kundu, 1998a, b). Hence, in testing our hypotheses, we control for local market potential, the general business conditions of the local 
market, the sociocultural distance between the local market and the entrant's home country, and the size of the entrant.

\section{METHODOLOGY}

\section{Sample}

Our empirical study is conducted in the global hotel industry. This industry exemplifies situations in which foreign market entrants can outsource business functions beyond production and distribution (e.g., operational management of the hotel). It also exemplifies the broader service industry, which is playing an increasingly important role in the global economy (Keegan, 2002).

The sample comprises members of the Global Hoteliers Club - specifically hotel general managers/managers who have worked on at least three continents. We sent the Club’s general managers/managers the questionnaire with a cover letter from the Club’s CEO, asking them to report on their individual hotel properties. After two follow-up letters, a total of 124 completed questionnaires (of the 558 originally mailed) were received. The response rate (22.2\%) is quite respectable when compared with similar studies using international samples.

Further, we concluded that non-response bias in our study was negligible. First, we sampled nonrespondents and asked them 10 questions contained in the original questionnaire. No significant differences were found between the respondent and non-respondent samples on these items. Second, the early respondents’ organizational demographics were comparable to those of later respondents, indicating an absence of non-response bias (Armstrong and Overton, 1977).

The final sample includes hotels from 53 countries, giving us a diversity of local markets. The hotels represented in the sample have parent companies that appear to be very heavily international, judging by the fact that they derive approximately $60.5 \%$ of their revenues internationally. Table 2 reports some additional characteristics about the sample. 


\section{Measures}

Based upon a review of the academic and trade literatures, we developed measures for the constructs under study. Some measures were adapted from previous research, whereas others were developed especially for this study. We refined the initial questionnaire based upon a pre-test of 50 international hotel general managers who attended an executive development program at a major US university.

Foreign market entry mode. We measured foreign market entry mode using two questions. We first asked hotel general managers to specify their hotel property’s type of firm. We next asked them whether their hotel property belonged to a franchise or marketing network. Note that only parent companies that operated more than one hotel were included in our analysis. Table 1 summarizes our measure of foreign market entry mode.

Market entrant's competitive advantage. We measured this construct by adapting 22 items from Chandler and Hanks (1994) to the hospitality industry. An exploratory factor analysis suggested a threefactor solution and also indicated that three items did not clearly fit into the domain of market entrant competitive advantage. Hence we dropped these items from our subsequent confirmatory factor analysis. The three-factor confirmatory measurement model fitted the data acceptably after dropping another six items that were either conceptually redundant or possessed excessively high residuals (see Appendix). All factor loadings were statistically significant $(P<0.01)$; the composite reliability coefficients exceeded 0.85 for the three constructs, well-above the usual 0.60 benchmark (Bagozzi and Yi, 1988); and none of the cross-construct correlations approached |1.0|, signifying the discriminant validity of these three dimensions of parent company competitive advantage (Phillips, 1981) - competitive advantage in generating customer service (CA_SVC), competitive advantage in terms of management and organization (CA_MGT), and competitive advantage in physical facilities (CA_FAC).

Local business conditions. Twenty questionnaire items, designed expressly for this study, were used to measure local business conditions. An exploratory factor analysis collapsed these 20 items into six factors. After dropping seven items that either were conceptually redundant or possessed excessively 
high residuals, we were able to develop a six-factor confirmatory measurement model that fitted the data adequately (Appendix). All factor loadings were statistically significant $(P<0.01)$; the composite construct reliability coefficients exceeded 0.80 ; and all of the cross-construct correlations were significantly smaller than |1.0|, indicating that our six local business condition factors (resource availability, RESOURCE; training costs, TNG_COST; availability of local investors, INVESTOR; market potential, MKT_POT; general business conditions, BSNSCOND; and sociocultural distance, DISTANCE) exhibited discriminant validity.

Parent company size. We measured parent company size as the respondent's report of the number of hotels operated by the parent company worldwide (SIZE). Table 2 provides more detail about the size and scope of the parent companies' international operations.

Table 3 reports the means, standard deviations, and intercorrelations of the measures used in this study.

\section{Data analysis}

In this study, we had a single categorical dependent variable (foreign entry mode) with four different groups (COA, MCU, MCA, and COU) as well as six hypothesized independent variables (CA_SVC, CA_MGT, CA_FAC, RESOURCE, TNG_COST, INVESTOR) and four control variables (MKT_POT, BSNSCOND, DISTANCE, SIZE). Therefore we used multinomial logistic regression to test the hypotheses (Sharma, 1996).

This technique estimates the impact of each independent variable upon the probability that a particular foreign market entry mode will be chosen (Klein et al., 1990). 'When the multinomial logit model is estimated, one option must be used as the base mode because once $\mathrm{j}$ - 1 alternative probabilities are known, the jth is determined' (Klein et al., 1990, 202). Thus we estimated three $(\mathrm{j}-1=3)$ different logit equations, beginning with the full ownership entry mode (i.e., COA) as the basis of comparison. The results of this analysis appear in Table 4. 


\section{RESULTS}

\section{Adequacy of fit}

Table 4 (footnote a) indicates that all three multinomial logistic functions were statistically significant $(P<0.05)$. In addition to statistical significance, we used classification adequacy to assess the multinomial logistic analysis. The first multinomial logistic function correctly classified $51.6 \%$ of the responding hotels, and the second and third functions accurately categorized 61.1 and $73.3 \%$, respectively. All three classification rates (Table 4, footnote $a$ ) were significantly (Po0.01) greater than

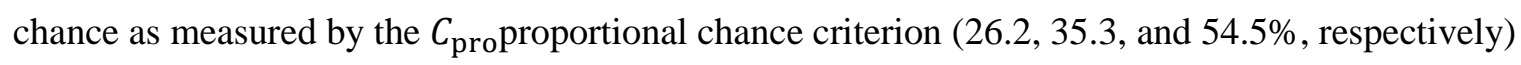
(Lehmann, 1989). Our classification rates possess an upward bias because we based our predictions on the same sample used to construct the logit functions (Lehmann, 1989). If we had had a larger sample, we would have divided it into an estimation subsample and a classification subsample to overcome this upward bias. However, because our hit rate is significantly larger than the $\mathrm{C}_{\text {pro }}$ criterion, the upward bias does not appear problematic in our research. Therefore both the statistical significance levels and the classification rates suggest that our multinomial logit functions fit the data adequately.

\section{Testing the hypotheses}

Hypothesis 1 argues that, when the entrant has established a competitive advantage in terms of customer service, it will utilize entry modes that afford it higher levels of operational and marketing control. Table 4 shows that the entrant's customer service competitive advantage is more likely to be associated with the MCU entry mode than with the $\operatorname{COU}\left(\beta_{\mathrm{MCU}} v s \mathrm{COU}=1.113, P<0.05\right)$, the COA $\left(\beta_{\mathrm{COA}} v s \mathrm{MCU}=-1.043, P<0.05\right)$, and the MCA entry mode $\left(\beta_{\mathrm{MCU}} v \mathrm{MCA}_{\mathrm{MCA}}=0.885, P<0.05\right)$ entry modes. The latter result (i.e., $\beta_{\mathrm{MCU}} v s_{\mathrm{MCA}}$ ) is consistent with $\mathrm{H} 1$. The difference between the two chainowned modes, in terms of the customer service competitive advantage, was not statistically significant. Therefore these results partially support H1. Hypothesis 2 states that the more that an entrant has established a competitive advantage on the basis of its management and organization, the more likely it is 
that it will use higher control entry modes. Table 4 shows that, the more the entrant has developed a competitive advantage in terms of management and organization, the less likely it is to utilize the COA entry mode relative to the: $\mathrm{COU}\left(\beta_{\mathrm{COA}} v s \mathrm{COU}=-0.990, P<0.05\right)$; $\mathrm{MCA}\left(\beta_{\mathrm{COA}} v s\right.$ MCA $=-1.489, P<$ 0.01); or MCU $\left(\beta_{\mathrm{COA}} v S \mathrm{MCU}=-0.974, P<0.05\right)$ entry modes. The first result is consistent with $\mathrm{H} 2$, whereas the others are not. These three results suggest that an affiliation with a franchise system or marketing network constrains an entrant's ability to transfer to chain-owned hotels its competitive advantage in terms of management and organization, as compared with the other entry modes.

Hypothesis 3 predicts that the more that the entrant has developed a competitive advantage in terms of its physical facilities, the more likely it is to use entry modes characterized by equity ownership but lower levels of marketing and operational control. Table 4 shows that, when the entrant establishes a physical facilities competitive advantage, it is more likely to use the COA entry mode relative to: the $\operatorname{COU}\left(\beta_{\mathrm{COA}} v S_{\mathrm{COU}}=0.418, P<0.10\right)$; the $\mathrm{MCA}\left(\beta_{\mathrm{COA}} v{ }_{\mathrm{MCA}}=0.755, P<0.10\right)$; or the $\mathrm{MCU}\left(\beta_{\mathrm{COA}} v s\right.$ $\mathrm{MCU}=0.838, P<0.05)$ entry modes. None of the other comparisons was statistically significant.

The significant, positive $\beta_{\mathrm{COA}} v \mathrm{~S}$ COU and $\beta_{\mathrm{COA}} v \mathrm{~s}$ MCU coefficients suggest that entrants select entry modes offering lower control over marketing and operations when they possesses a competitive advantage in terms of physical facilities. The significant, positive $\beta_{\mathrm{COA}} v \mathrm{~S}$ COU and $\beta_{\mathrm{COA}} v S$ MCU coefficients indicate that entrants employ ownership entry modes when they possess a physical facilities competitive advantage. Thus these results partially support H3.

In H4, we argue that the more resources are available in local markets, the more likely it is that the firm will utilize entry modes that offer lower levels of control. Consistent with this hypothesis, Table 4 shows that, when local resources are available, the entrant is more likely to employ the COA entry mode than the COU entry mode $\left(\beta_{\mathrm{COA}} v s \mathrm{COU}=0.680, \mathrm{P}<0.05\right)$ and less likely to use the MCU mode than the MCA mode $\left(\beta_{\mathrm{MCU}} v s\right.$ MCA $\left.=-0.736, P<0.05\right)$. Unexpectedly, the COA entry mode is more likely to be employed than the MCU entry mode $\left(\beta_{\mathrm{COA}} v s \mathrm{COU}=0.606, P<0.10\right)$ under these same conditions. Overall, however, we found partial support for this hypothesis. 
Hypothesis 5 argues that the higher the costs of training in the local market, the more likely it is that the entrant will use foreign market entry modes characterized by higher levels of control over marketing and operations. Table 4's results show that the entrant is more likely to use the MCU mode relative to the $\mathrm{COU}\left(\beta_{\mathrm{MCU}}\right.$ vs $\left.\mathrm{COU}=0.414, P<0.10\right)$ and the $\mathrm{MCA}\left(\beta_{\mathrm{MCU}} \mathrm{VS} \mathrm{MCA}_{\mathrm{MC}}=0.407, P<0.10\right)$ modes when local market training costs are higher. The latter finding is consistent with our a priori expectations, but the former is not. Hence these results partially support H5.

The sixth hypothesis argues that entrants are more likely to use low equity foreign market entry modes, the greater the availability of local investors. Table 4 indicates that, the more that local investors are available, the less likely entrants are to use the COA entry mode relative to the MCA entry mode $\left(\beta_{\mathrm{COA}} v{ }_{\mathrm{MCA}}=-0.585, P<0.05\right)$. This finding partially supports $\mathrm{H} 6$, although none of the other parameter estimates for INVESTOR were statistically significant.

In terms of the control variables, we found that local market potential had no significant $(P>$ 0.10) bearing upon the market entry mode chosen (Table 4), contrary to previous findings (Contractor and Kundu, 1998a). The local market’s general business conditions were, however, significantly $(P<0.10)$ associated with foreign market entry mode. Table 4 generally indicates that the more favorable the local business conditions, the more likely the entrant is to use the COA entry mode relative to the others ( $P<$ 0.10) and, between the management company modes, the more likely it is that the entrant will use the MCU mode ( $P<0.10)$. These results are generally consistent with previous empirical findings (Hill et al., 1990; Contractor and Kundu, 1998a, b). In addition, entrants that experience a larger sociocultural distance between the local market and their home markets are less likely $(P<0.10)$ to utilize the COU entry mode than the others studied here (Table 4). This finding is also generally consistent with previous empirical research (Anderson and Gatignon, 1986; Erramilli and Rao, 1993; Contractor and Kundu, 1998a; Ekeledo and Sivakumar, 1998). Finally, larger entrants are significantly $(P<0.05)$ more likely to use the MCA entry mode relative to the three others (Table 4). This result supports the notion that firms grow in size by 'building a network of alliances’ with management companies, franchise systems, and marketing networks (Contractor and Kundu, 1998a, 351). ${ }^{1}$ 


\section{DISCUSSION}

In this paper, our perspective is that foreign market entry mode decisions must be made for every business activity (such as production, distribution, $R \& D$, sales and marketing, management) that is to be performed on behalf of the foreign market (Stern et al., 1989), not just those involving production and distribution (Buckley and Casson, 1998; Ekeledo and Sivakumar, 1998). For this reason, we separate the ownership dimension of foreign market entry mode from the control dimension, and specifically control over marketing and operations (Pan and Tse, 2000).

Another goal of this paper was to understand the entry modes by which firms transfer their competitive advantages to foreign markets. In particular, we investigate how the choice of entry mode is affected by:

(1) the entrant's ability to transfer its competitive advantages to the foreign market;

(2) the ability of local partners to leverage those competitive advantages to the market entrant's benefit;

(3) the availability of qualified and trustworthy local partners.

\section{Managerial implications}

The key findings are summarized in Table 5. They suggest that the ownership dimension is associated with the capacity of the local market to absorb the entrant's competitive advantages. For example, when trustworthy and qualified investors are available in the local market, the absorptive capacity of the local market is higher, enabling the firm to use the management company entry mode Broadening foreign market entry mode rather than the ownership mode to transfer its competitive advantages. For example, when trustworthy and qualified investors are available in the local market, the absorptive capacity of the local market is higher, enabling the firm to use the management company entry mode rather than the ownership mode to transfer its competitive advantages. This is especially true when a franchise or marketing network affiliation is involved. However, when the cost of training managers and employees in the local market is high (i.e., the local market absorptive capacity is low), the management 
company entry mode (especially, the MCU mode) is preferred to ownership. In this situation, the entrant can capitalize on the management company’s expertise to manage and staff the hotel property, and thereby avoid incurring the high costs of hiring and training local employees. Tacit knowledge in terms of competitive advantage (e.g., customer service, management, and organization) favors the management company entry mode relative to ownership, except in the case of the COU mode. Apparently, partnering with a management company, franchise system/marketing network, or both enables the entrant to transfer its tacit competitive advantage.

The dictates of the franchise system or the marketing network affiliations generally seem to hinder the entrant's ability to transfer the tacit aspects of its competitive advantage. Where the entrant affiliates with a franchise system or marketing network, it is more likely to employ the management company entry mode rather than ownership, when it has established a competitive advantage in terms of management and organization. This enables the entrant to focus on its management and organizational advantages, particularly when the franchise system or marketing network provides marketing and operational support.

Similarly, a marketing affiliation (i.e., lower control over marketing and operations) is associated with local markets whose absorptive capacity is high, such as when sufficient resources (including qualified and trustworthy investors) are relatively easy to procure in the local market. In other words, entrants appear to use lower control modes such as marketing affiliations to enter markets that are relatively munificent.

The entrant's codified knowledge in the form of its physical facilities competitive advantage is generally associated with chain ownership of the hotel property in the local market, especially when the entrant is affiliated with a franchise system or marketing network. This finding suggests that the entrant can build hotels to its specification more easily when it retains ownership over the hotel properties in its local markets. Apparently, any competitive advantage rooted in physical facilities cannot be readily transferred to the local market through the management company entry mode. 


\section{Research implications}

The hotel industry provides an interesting setting in which to study foreign market entry modes. This industry exemplifies situations in which business activities such as ownership and control over marketing and operations can be separated to a much greater degree than in other lines of trade where ownership and operations tend to go hand in hand. Most research assumes the latter perspective. However, our findings indicate that such might not be the case, and that a more complex perspective on foreign market entry mode should be taken.

For example, our research shows that firms can transfer tacit competitive advantages (e.g., competitive advantage in customer service and in management and organization) through the management company entry mode. Theory and previous empirical research, based upon a unidimensional description of foreign market entry mode, argue that these advantages are better transferred via ownership. Because the management company entry mode is considered to be a relative high control entry mode under this perspective (Contractor and Kundu, 1998a; Olsen et al., 1998), our finding would have been masked had we taken the unidimensional perspective.

For this reason, we believe that, at a minimum, researchers should separate the business activities of ownership and control over day-to-day operations in their investigations of foreign market entry modes. We also recommend that future researchers consider separate market entry modes for other business functions such as responsibility for marketing planning (branding, product line, positioning), control over physical assets, responsibility for R\&D, and so forth. We believe that our research represents a first step in that direction.

As with any study, ours has a number of limitations that suggest directions for future research. First, the sample is composed of hotels: therefore samples from other industries are needed to generalize our findings. Further, because our sample represents scores of countries, the results may not be applicable to any one country. However, because we control for sociocultural distance, this weakness may not be overly limiting. Second, further research might develop a more fully specified empirical model to include explicit transaction cost factors, additional firm variables (such as experience in international markets, 
extent of international operations), and additional strategic factors (such as strategic orientation of the entrant firm as well as the specific hotel property). Third, because our study was cross-sectional, we have no way of knowing whether the governance structure currently used is the initial foreign market entry mode. Additional methods such as archival research are needed to determine this. Finally, our measure of foreign market entry mode was based upon whether the local hotel was operated independently or by a management company and whether or not it was affiliated with a franchise system or marketing network. Our study points out that additional research is needed to operationalize the foreign market entry mode construct more fully.

\section{Contributions}

The contributions of this research are threefold. First, we found that the ownership dimension of the foreign market entry mode decision could be separated from its control dimension. Next, we broadened the conceptualization of foreign market entry mode beyond production and distribution to include any business activity that firms may outsource upon entering local markets. Finally, we examined specific, but generalizable, aspects of competitive advantage. In particular, we found competitive advantage based on tacit knowledge (e.g., competitive advantage in terms of customer service or management and organization) and codified knowledge (e.g., competitive advantage in terms of physical facilities) to be differentially related to the ownership and control dimensions of the foreign market entry mode decision. The overall contribution of this study is our finding that foreign market entry mode is not neatly described by the traditional, unidimensional continuum based upon ownership, resource commitment, and control. Indeed, our findings suggest that future research should develop a richer conceptualization of the foreign market entry mode construct - one that acknowledges the necessity of separate foreign market entry decisions for each business activity that may be outsourced to a local market partner. 


\section{NOTES}

1. We also utilized discriminant analysis to investigate the hypotheses. Overall, this analysis was generally consistent with our logistic regression findings. The authors will provide interested readers with these results upon request. 


\section{REFERENCES}

Achrol, R.S. (1997) 'Changes in the theory of interorganizational relations in marketing: toward a network paradigm', Journal of the Academy of Marketing Science 25: 56-71.

Andersen, O. (1997) 'Internationalization and market entry mode: a review of theories and conceptual frameworks’, Management International Review 37(Special Issue): 27-42.

Anderson, E. and Coughlan, A.T. (1987) 'International market entry and expansion via independent or integrated channels of distribution', Journal of Marketing 51: 71-82.

Anderson, E. and Gatignon, H. (1986) 'Modes of foreign entry: a transaction cost analysis and propositions', Journal of International Business Studies 17: 1-26.

Armstrong, J.S. and Overton, T.S. (1977) ‘Estimating nonresponse bias in mail surveys’, Journal of Marketing Research 14: 396-402.

Aulakh, P.S. and Kotabe, M. (1997) 'Antecedents and performance implications of channel integration in foreign markets', Journal of International Business Studies 28(First Quarter): 145-175.

Bagozzi, R.P. and Yi, Y. (1988) 'On the evaluation of structural equation models', Journal of the Academy of Marketing Science 16: 74-94.

Barney, J.B. (1986) 'Strategic factor markets: expectations, luck and business strategy', Management Science 32: 1231-1241.

Barney, J.B. (1991) 'Firm resources and sustained competitive advantage', Journal of Management 17: 99-120.

Bartlett, C.A. and Ghoshal, S. (1998) Managing Across Borders: The Transnational Solution, Harvard Business School Press: Boston.

Bello, D.C. and Gilliland, D.I. (1997) 'The effect of output controls, process controls, and flexibility on export channel performance', Journal of Marketing 61: 22-38. 
Bharadwaj, S.G., Varadarajan, R. and Fahy, J. (1993) 'Sustainable competitive advantage in service industries: a conceptual model and research propositions’, Journal of Marketing 57: 83-99.

Bradley, F. and Gannon, M. (2000) ‘Does the firm’s technology and marking profile affect market entry?', Journal of International Marketing 8(4): 12-36.

Buckley, P.J. and Casson, M.C. (1998) 'Analyzing foreign market entry strategies: extending the internalization approach', Journal of International Business Studies 29(Third Quarter): 539-562.

Burgel, O. and Murray, G.C. (2000) 'The international market entry choices of start-up companies in high-technology industries', Journal of International Marketing 8(2): 33-62.

Chandler, G.N. and Hanks, S.H. (1994) 'Market attractiveness, resource-based capabilities, venture strategies, and venture performance', Journal of Business Venturing 9: 331-349.

Cohen, W.M. and Levinthal, D.A. (1990) 'Absorptive capacity: a new perspective on learning and innovation', Administrative Science Quarterly 35: 128-152.

Conner, K.R. (1991) ‘A historical comparison of resource-based theory and five schools of thought within industrial organization economics: do we have a new theory of the firm?', Journal of Management 17: 121-154.

Conner, K.R. and Prahalad, C.K. (1996) ‘A resource-based theory of the firm: knowledge versus opportunism', Organization Science 7: 477-501.

Contractor, F.J. and Kundu, S.K. (1998a) 'Modal choice in a world of alliances: analyzing organizational forms in the international hotel sector', Journal of International Business Studies 29(Second Quarter): $325-358$.

Contractor, F.J. and Kundu, S.K. (1998b) 'Franchising versus company-run operations: modal choice in the global hotel sector', Journal of International Marketing 6(2): 28-53. 
Day, G.S. and Wensley, R. (1988) ‘Assessing advantage: a framework for diagnosing competitive superiority’, Journal of Marketing 52: 1-20.

Dunning, J.H. and McQueen, M. (1981) ‘The eclectic theory of international production: a case study of the international hotel industry’, Managerial and Decision Economics 2(4): 197-210.

Ekeledo, I. and Sivakumar, K. (1998) 'Foreign market entry mode choice of service firms: a contingency perspective', Journal of the Academy of Marketing Science 26(4): 274-292.

Erramilli, M.K., Agarwal, S. and Dev, C.S. (2002) 'Choice between non-equity entry modes: an organizational capability perspective’, Journal of International Business Studies 33(2): 223-242.

Erramilli, M.K. and Rao, C.P. (1990) 'Choice of foreign market entry modes by service firms: role of market knowledge’, Management International Review 30(Second Quarter): 135-150.

Erramilli, M.K. and Rao, C.P. (1993) ‘Service firms’ international entry-mode choice: a modified transaction-cost analysis approach', Journal of Marketing 57: 19-38.

Gatignon, H., Weitz, B. and Bansal, P. (1990) 'Brand introduction strategies and competitive environments', Journal of Marketing Research 27: 390-401.

Hill, C.W.L., Hwang, P. and Kim, W.C. (1990) 'An eclectic theory of the choice of international entry mode’, Strategic Management Journal 11(2): 117-128.

Keegan, W.J. (2002) Global Marketing Management, 7th edn Prentice-Hall: Upper Saddle River, NJ.

Kim, W.C. and Hwang, P. (1992) 'Global strategy in multinationals’ entry mode choice’, Journal of International Business Studies 22(First Quarter): 29-53.

Klein, S., Frazier, G.L. and Roth, V.J. (1990) 'A transaction cost analysis model of channel integration in international markets', Journal of Marketing Research 27: 196-208.

Kogut, B. and Zander, U. (1992) 'Knowledge of the firm, combinative capabilities, and the replication of technology’, Organization Science 3: 383-397. 
Lehmann, D.R. (1989) Market Research and Analysis, 3rd edn Irwin: Homewood, IL.

Luo, Y. (1999) Entry and Cooperative Strategies in International Business Expansion, Quorum Books: Westport, CT.

Luo, Y. (2001) 'Determinants of entry in an emerging economy: a multilevel approach', Journal of Management Studies 38(3): 443-472.

Madhok, A. (1997) 'Cost, value and foreign market entry mode: the transaction and the firm', Strategic Management Journal 18: 39-61.

Narver, J.C. and Slater, S.F. (1990) ‘The effect of a market orientation on business profitability’, Journal of Marketing 54: 20-35.

Olsen, M., West, J. and Tse, E.C.Y. (1998) Strategic Management in the Hospitality Industry, 2nd edn John Wiley \& Sons: New York.

Pan, Y. and Tse, D.K. (2000) 'The hierarchical model of market entry modes', Journal of International Business Studies 31(Fourth Quarter): 535-554.

Phillips, L.W. (1981) ‘Assessing measurement error in key informant reports: a methodological note on organizational analysis in marketing', Journal of Marketing Research 18: 395-415.

Polanyi, M. (1966) The Tacit Dimension, Anchor Day Books: New York.

Sharma, S. (1996) Applied Multivariate Techniques, John Wiley \& Sons: New York.

Stern, L.W., El-Ansary, A.I. and Brown, J.R. (1989) The Management of Marketing Channels, PrenticeHall: Englewood Cliffs, NJ.

Teece, D.J. (1980) 'Economies of scope and the scope of the enterprise', Journal of Economic Behavior and Organization 1: 223-247.

Walker Jr, O.C. (1997) ‘The adaptability of network organizations: some unexplored questions’, Journal of the Academy of Marketing Science 25: 75-82. 
Wernerfelt, B. (1984) ‘A resource-based view of the firm', Strategic Management Journal 5: 171-180. 
Table 1. Two dimensions of the foreign market entry mode decision: examples from the international hotel industry.

Control over marketing and operations ${ }^{a}$

Ownership of physical facilities ${ }^{\mathrm{b}}$

(i.e., independent) owner/operator. majority owner/operator, or minority owner/operator (higher ownership)

\section{Third-party management company} (no ownership)

\section{Membership in a franchise system or marketing network \\ (lower entrant control) \\ No membership in a franchise system or marketing network \\ (higher entrant control)}

\section{COA}

Marriott, Karachi

Hotel Inter-Continental, Kinshasa

Holiday Inn Park View, Singapore

\section{MCA}

Sheraton Four Points, Dubai

Ramada International, Frankfurt

Novotel Ambassador, Seoul

\section{$\mathrm{COU}$}

Shangri-La Hotel, Manila

Sea Garden Hotel, Turkey

Hotel Grande Bretagne, Athens

\section{$M C U$}

Hotel Sedona Makassar, Indonesia

Hotel George V, Paris

Le Montreux Palace, Switzerland

'This dimension represents the extent to which the market entrant develops its own operating systems and/or marketing programs or relies upon those established by a marketing network or franchise system.

'This dimension represents the extent to which the foreign market entrant invests in the hotel's physical assets (i.e., land, physical plant). 
Table 2. Salient characteristics of the sample

\begin{tabular}{|c|c|c|}
\hline \multicolumn{3}{|l|}{ Geographic origin } \\
\hline \multirow[t]{2}{*}{ Continent } & \multicolumn{2}{|c|}{ Frequency } \\
\hline & Absolute & Relative (\%) \\
\hline Africa & 12 & 9.7 \\
\hline Asia & 54 & 43.5 \\
\hline Australia & 11 & 8.9 \\
\hline Europe & 28 & 22.6 \\
\hline South America & 4 & 3.2 \\
\hline North America & 15 & 12.1 \\
\hline Total & 124 & 100.0 \\
\hline \multicolumn{3}{|l|}{ Size of operations } \\
\hline & Mean & \\
\hline No. of hotels in worldwide chain & 348.6 & \\
\hline No. of rooms per hotel property & 368.6 & \\
\hline No. of employees per hotel property & 455.1 & \\
\hline \multicolumn{3}{|l|}{ Parent's international scope } \\
\hline & Mean & \\
\hline $\begin{array}{l}\text { Years of international operations } \\
\text { Percentage of revenues from } \\
\text { international operations }\end{array}$ & $\begin{array}{l}29.2 \\
60.5\end{array}$ & \\
\hline \multicolumn{3}{|l|}{ Years of operations } \\
\hline & Mean & \\
\hline Years hotel has been open & 21.1 & \\
\hline $\begin{array}{l}\text { No. of years under present } \\
\text { management }\end{array}$ & 8.5 & \\
\hline \multicolumn{3}{|l|}{ Entry mode } \\
\hline & Absolute & Relative (\%) \\
\hline COA & 21 & 16.9 \\
\hline $\mathrm{MCU}$ & 39 & 31.5 \\
\hline MCA & 35 & 28.2 \\
\hline $\mathrm{COU}$ & 29 & 23.4 \\
\hline Total & 124 & 100.0 \\
\hline
\end{tabular}


Table 3. Matrix of intercorrelations, means, and standard deviations ${ }^{\mathrm{a}}$

\begin{tabular}{|c|c|c|c|c|c|c|c|c|c|c|c|c|c|c|}
\hline \multirow[t]{2}{*}{ Variable } & \multicolumn{14}{|c|}{ Variable } \\
\hline & 1. & 2. & 3. & 4. & 5. & 6. & 7. & 8. & 9. & 10. & 11. & 12. & 13. & 14. \\
\hline 1. $\mathrm{COA}$ & 1.000 & & & & & & & & & & & & & \\
\hline 2. $\mathrm{COU}$ & $-0.249^{b}$ & 1.000 & & & & & & & & & & & & \\
\hline 3. $\mathrm{MCU}$ & $-0.306^{b}$ & $-0.374^{b}$ & 1.000 & & & & & & & & & & & \\
\hline 4. MCA & $-0.283^{b}$ & 0.000 & 0.000 & 1.000 & & & & & & & & & & \\
\hline 5. CA_SVC & -0.050 & -0.112 & $0.194^{c}$ & -0.053 & 1.000 & & & & & & & & & \\
\hline 6. CA_MGT & $-0.196^{c}$ & -0.061 & 0.095 & 0.123 & $0.558^{\mathrm{b}}$ & 1.000 & & & & & & & & \\
\hline 7. CA_FAC & 0.078 & -0.001 & -0.039 & -0.024 & $0.542^{b}$ & $0.401^{b}$ & 1.000 & & & & & & & \\
\hline 8. RESOURCE & $0.203^{c}$ & 0.021 & $-0.22 T^{c}$ & 0.045 & 0.126 & 0.079 & $0.279^{b}$ & 1.000 & & & & & & \\
\hline 9. STAFCOST & -0.015 & -0.054 & 0.111 & -0.052 & -0.107 & -0.122 & -0.126 & -0.112 & 1.000 & & & & & \\
\hline 10. INVESTOR & 0.068 & 0.023 & $-0.186^{c}$ & 0.114 & -0.085 & -0.073 & 0.022 & $0.361^{\mathrm{b}}$ & 0.023 & 1.000 & & & & \\
\hline 11. MKT_POT & 0.054 & 0.013 & -0.092 & 0.038 & 0.142 & -0.065 & 0.172 & $0.260^{b}$ & -0.119 & $0.244^{\mathrm{b}}$ & 1.000 & & & \\
\hline 12. BSNSCOND & $0.200^{c}$ & 0.049 & -0.112 & -0.097 & 0.043 & 0.042 & 0.124 & $0.465^{b}$ & $-0.273^{b}$ & $0.202^{c}$ & $0.290^{\mathrm{b}}$ & 1.000 & & \\
\hline 13. DISTANCE & -0.086 & $-0.195^{c}$ & $0.176^{c}$ & 0.073 & -0.010 & 0.068 & $-0.208^{c}$ & $-0.485^{b}$ & 0.042 & $-0.188^{c}$ & -0.161 & $-0.424^{b}$ & 1.000 & \\
\hline 14. SIZE & -0.082 & -0.073 & -0.128 & $0.269^{b}$ & -0.145 & 0.057 & -0.149 & -0.086 & -0.010 & 0.004 & -0.058 & 0.043 & 0.111 & 1.000 \\
\hline Mean & 0.169 & 0.234 & 0.315 & 0.282 & 3.739 & 3.657 & 3.760 & 2.723 & 2.508 & 2.722 & 3.597 & 3.519 & 3.766 & 348.613 \\
\hline s.d. & 0.377 & 0.425 & 0.466 & 0.452 & 0.826 & 0.803 & 0.841 & 0.938 & 0.971 & 0.907 & 0.995 & 1.021 & 1.150 & 638.056 \\
\hline
\end{tabular}

${ }^{b} p<0.01$ (two-tailed)

${ }^{c} p<0.05$ (two-tailed). 
Table 4. Logistic regression parameter estimates ${ }^{\mathrm{a}}$

\begin{tabular}{|c|c|c|c|c|c|c|c|c|c|c|c|}
\hline \multirow[t]{2}{*}{ Option } & \multicolumn{11}{|c|}{ Parameter estimates } \\
\hline & Intercept & CA_SVC & CA_MGT & $C A \_F A C$ & RESOURCE & TNG_COST & INVESTOR & MKT_POT & BSNSCOND & DISTANCE & SIZE \\
\hline \multicolumn{12}{|l|}{ (a) Comparison with $\mathrm{COU}$} \\
\hline \multirow[t]{2}{*}{ COA } & $-5.324^{\mathrm{d}}$ & 0.279 & $-0.990^{c}$ & $0.418^{\mathrm{d}}$ & $0.680^{d}$ & 0.278 & -0.179 & -0.176 & $0.620^{d}$ & $0.566^{c}$ & 0.000 \\
\hline & (3.305) & $(0.503)$ & $(0.511)$ & $(0.494)$ & $(0.427)$ & $(0.358)$ & $(0.373)$ & $(0.326)$ & $(0.403)$ & $(0.315)$ & $(0.001)$ \\
\hline $\mathrm{MCU}$ & $\begin{array}{l}-4.505^{\mathrm{d}} \\
(2.958)\end{array}$ & $\begin{array}{l}1.113^{c} \\
(0.491)\end{array}$ & $\begin{array}{l}-0.160 \\
(0.461)\end{array}$ & $\begin{array}{r}-0.322 \\
(0.414)\end{array}$ & $\begin{array}{r}-0.169 \\
(0.392)\end{array}$ & $\begin{array}{l}0.414^{\mathrm{d}} \\
(0.301)\end{array}$ & $\begin{array}{l}-0.215 \\
(0.330)\end{array}$ & $\begin{array}{r}-0.102 \\
(0.298)\end{array}$ & $\begin{array}{c}0.188 \\
(0.343)\end{array}$ & $\begin{array}{r}0.555^{c} \\
(0.298)\end{array}$ & $\begin{array}{r}0.000 \\
(0.001)\end{array}$ \\
\hline \multirow[t]{2}{*}{ MCA } & $-3.899^{\mathrm{d}}$ & 0.125 & 0.396 & -0.148 & 0.467 & -0.047 & 0.216 & 0.132 & -0.406 & $0.419^{d}$ & $0.001^{c}$ \\
\hline & $(2.963)$ & $(0.448)$ & $(0.463)$ & $(0.418)$ & $(0.389)$ & $(0.309)$ & $(0.327)$ & $(0.292)$ & $(0.343)$ & $(0.283)$ & $(0.000)$ \\
\hline \multicolumn{12}{|l|}{ (b) Comparison with MCA } \\
\hline \multirow{2}{*}{ COA } & 1.154 & -0.301 & $-1.489^{b}$ & $0.755^{d}$ & 0.027 & 0.452 & $-0.585^{\mathrm{d}}$ & -0.299 & $1.268^{\mathrm{b}}$ & -0.227 & $-0.001^{\circ}$ \\
\hline & (3.474) & $(0.536)$ & $(0.551)$ & $(0.536)$ & $(0.423)$ & $(0.368)$ & $(0.406)$ & $(0.368)$ & $(0.461)$ & $(0.343)$ & $(0.001)$ \\
\hline MCU & $\begin{array}{l}0.629 \\
(2.934)\end{array}$ & $\begin{array}{l}0.885^{c} \\
(0.472)\end{array}$ & $\begin{array}{c}-0.512 \\
(0.466)\end{array}$ & $\begin{array}{c}-0.124 \\
(0.402)\end{array}$ & $\begin{array}{r}-0.736^{c} \\
(0.385)\end{array}$ & $\begin{array}{l}0.407^{d} \\
(0.300)\end{array}$ & $\begin{array}{c}-0.397 \\
(0.319)\end{array}$ & $\begin{array}{c}-0.186 \\
(0.315)\end{array}$ & $\begin{array}{l}0.564^{d} \\
(0.349)\end{array}$ & $\begin{array}{c}-0.098 \\
(0.312)\end{array}$ & $\begin{array}{r}-0.001 \\
(0.000)\end{array}$ \\
\hline \multicolumn{12}{|l|}{ (b) Comparison with MCU } \\
\hline \multirow[t]{2}{*}{ COA } & $\begin{array}{l}1.636 \\
(3.398)\end{array}$ & $\begin{array}{r}-1.043^{c} \\
(0.594)\end{array}$ & $\begin{array}{r}-0.974^{c} \\
(0.494)\end{array}$ & $\begin{array}{r}0.838^{c} \\
(0.492)\end{array}$ & $\begin{array}{l}0.606^{\mathrm{d}} \\
(0.458)\end{array}$ & $\begin{array}{c}0.079 \\
(0.359)\end{array}$ & $\begin{array}{l}-0.240 \\
(0.478)\end{array}$ & $\begin{array}{c}-0.246 \\
(0.378)\end{array}$ & $\begin{array}{r}0.682^{\mathrm{d}} \\
(0.463)\end{array}$ & $\begin{array}{c}-0.241 \\
(0.348)\end{array}$ & $\begin{array}{r}0.000 \\
(0.001)\end{array}$ \\
\hline & \multicolumn{11}{|c|}{ Comparison } \\
\hline${ }^{a}$ Goodness-of-fit statistic & a & b & c & & & & & & & & \\
\hline$-2 \log$ likelihood & 287.009 & 159.265 & 58.301 & & & & & & & & \\
\hline$x^{2}$ & $50.615^{c}$ & $43.470^{b}$ & $19.392^{c}$ & & & & & & & & \\
\hline df & 30 & 20 & 10 & & & & & & & & \\
\hline Cox and Snell pseudo $R^{2}$ & 0.335 & 0.367 & 0.276 & & & & & & & & \\
\hline Correct classification rate (\%) & 51.6 & 61.1 & 73.3 & & & & & & & & \\
\hline $\begin{array}{l}C_{\text {pro }}(\%) \\
z \text {-Score }\end{array}$ & $\begin{array}{l}26.2 \\
6.437^{b}\end{array}$ & $\begin{array}{l}35.3 \\
5.249^{b}\end{array}$ & $\begin{array}{l}54.5 \\
2.930^{\mathrm{b}}\end{array}$ & & & & & & & & \\
\hline$N$ & 124 & 95 & 60 & & & & & & & & \\
\hline
\end{tabular}

${ }^{b_{p}<0.01 .}$

${ }^{C} p<0.05$.

${ }^{d} p<0.10$. 
Table 5. Conditions favoring each foreign market entry mode: summary of results

\begin{tabular}{|c|c|c|}
\hline \multirow[t]{2}{*}{ Ownership dimension } & \multicolumn{2}{|l|}{ Marketing and operations dimension } \\
\hline & $\begin{array}{l}\text { Affiliated with franchise system or } \\
\text { marketing network (lower entrant } \\
\text { control) }\end{array}$ & $\begin{array}{l}\text { Not affiliated with franchise } \\
\text { system or marketing network } \\
\text { (higher entrant control) }\end{array}$ \\
\hline $\begin{array}{l}\text { Sole (i.e., independent) owner/operator, } \\
\text { majority owner/operator, or minority owner/ } \\
\text { operator (higher ownership) }\end{array}$ & $\begin{array}{l}\text { Chain-owned, affiliated } \\
\text { ๑ Physical facilities competitive } \\
\text { advantage } \\
\text { - Plentiful local resources }\end{array}$ & $\begin{array}{l}\text { Chain-owned, unaffiliated } \\
\text { - Management and } \\
\text { organization competitive } \\
\text { advantage }\end{array}$ \\
\hline $\begin{array}{l}\text { Third-party management company (no } \\
\text { ownership) }\end{array}$ & $\begin{array}{l}\text { Management company, } \\
\text { affiliated } \\
\text { Management and } \\
\text { organization competitive } \\
\text { advantage } \\
\text { Plentiful local resources } \\
\text { - Locally available, qualified } \\
\text { and trustworthy investors }\end{array}$ & $\begin{array}{l}\text { Management company, } \\
\text { unaffiliated } \\
\text { customer service } \\
\text { competitive advantage } \\
\text { - Management and } \\
\text { organization competitive } \\
\text { advantage } \\
\text { - High local market training } \\
\text { costs }\end{array}$ \\
\hline
\end{tabular}




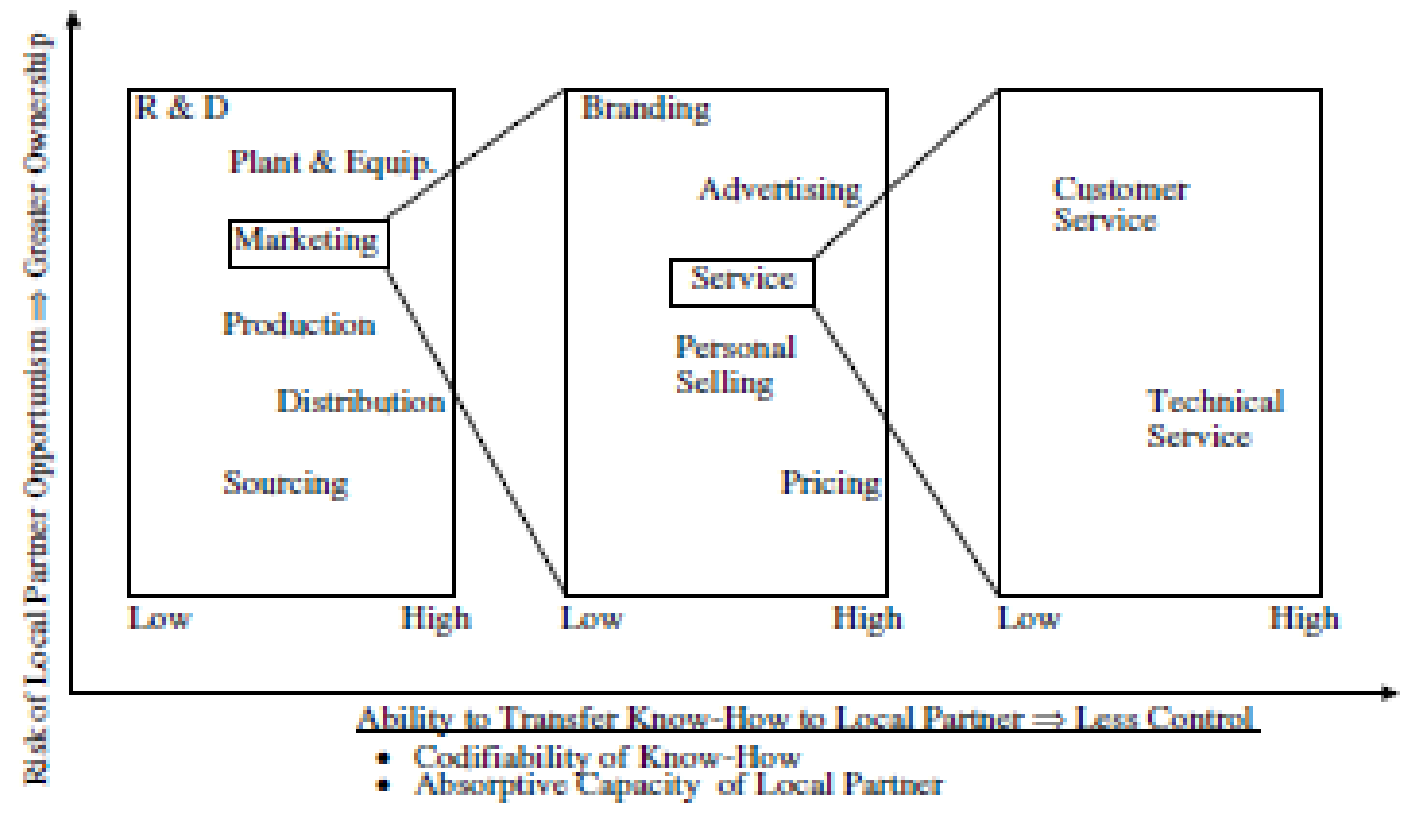

Figure 1. Factors affecting the separation of ownership and control for various business functions when entering foreign markets.

Source: Adapted from Bartlett and Ghoshal (1998, Figure 6.1). 


\section{APPENDIX:}

\section{Questionnaire items}

\section{Parent company competitive advantage ${ }^{a}$}

$x^{2}=205.32, \mathrm{df}=62, P=0.00 ; \mathrm{GFI}=0.86, \mathrm{CFI}=0.93$.

1. Generating customer service (CA_SVC; $p=0.914)$
(a) Finding good locations (CA1) ${ }^{\mathrm{b}}$.
(b) Creating customer base (CA4) ${ }^{\mathrm{b}}$.
(c) Creating repeat business (CA5) ${ }^{\mathrm{b}}$.
(d) Ensuring service quality (CA6).
(e) Ensuring customer satisfaction (CA8).
(f) Providing appropriate services (CA13) ${ }^{\mathrm{b}}$.
(g) Quality of guest-contact staff (CA14).
(h) Quality of managerial team (CA15).
(i) Teamwork among employees (CA16).

2. Management and organization (CA_MGT; $\rho=0.850)^{b}$
(a) Knowing the right time to enter (CA2) ${ }^{b}$.
(b) Creating the brand reputation (CA3) ${ }^{b}$.
(c) Establishing a chain operation (CA7) ${ }^{b}$.
(d) Company culture (CA17).
(e) Operating policies and procedures (CA18).
(f) Implementing employee empowerment (CA19).
(g) Quality of reservation system (CA20) ${ }^{b}$.
(h) Information technology systems (CA21). 
3. Physical facility (CA_FAC; $\rho=0.932)$

(a) Quality of physical facilities (CA9).

(b) Decor/design of properties (CA10).

(c) Ambience/atmosphere of properties (CA11).

(d) Comfort of physical facilities (CA12).

\section{Local business conditions facing hotel's parent company}

$x^{2}=126.49, \mathrm{df}=53, P=0.00 ; \mathrm{GFI}=0.91, \mathrm{CFI}=0.93$.

1. Resource availability (RESOURCE; $\rho=0.829$ )

(a) Availability of qualified service employees (OC1) ${ }^{c}$.

(b) Availability of qualified managerial staff (OC2) ${ }^{d}$.

(c) Availability of reliable suppliers (OC3) ${ }^{d}$.

(d) Quality of supplies for your hotel (BC4) ${ }^{b, d}$

2. Training costs (TNG_COST; $\rho=0.876$ )

(a) Cost of training service employees (OC4) ${ }^{c}$.

(b) Cost of training managerial staff (OC5) ${ }^{c}$.

3. Availability of local investment partners (INVESTOR; $\rho=0.810$ )

(a) Availability of qualified local investment partners to your parent company for establishing new hotels (OC7) ${ }^{c}$.

(b) Availability of trustworthy local investment partners to your parent company for establishing new hotels (OC8) ${ }^{c}$.

4. Market potential (MKT_POT; $\rho=0.850)^{e}$ 
(a) Size of the hotel market (MC1) ${ }^{f}$

(b) Potential for growth in the hotel market (MC2) ${ }^{b, f}$.

5. Local market's general business conditions (BSNSCOND; $\rho=0.821$ )

(a) Political relations between the host and home country (BC1) ${ }^{b, d}$.

(b) Government restrictions on operations of foreign hotels (BC2) ${ }^{b, d}$.

(c) Reputation of your hotel's brand (BC3) ${ }^{b, d}$.

(d) Quality of infrastructure (phones, roads, etc.) (BC5) ${ }^{c}$.

(e) General business conditions (BC6) ${ }^{d}$.

(f) Political stability (BC7) ${ }^{d}$.

(g) Aggressiveness of competitors (OC6) ${ }^{b, c}$

(h) Number of new competitors expected to enter your market in the next 5 years (MC3) ${ }^{b, c}$

6. Sociocultural distance (DISTANCE; $\rho=0.883$ )

(a) Differences in business practices between this country and the parent's home country (MC4) ${ }^{f}$.

(b) Differences in culture between this country and the parent's home country (MC5) ${ }^{f}$.

aAnchored by “'1”' (no advantage) and “5”’ (great advantage).

${ }^{b}$ Deleted from further analysis.

cAnchored by “'1”' (very low) and “5”’ (very high).

'Anchored by “'1'” (very poor) and “5”’ (very good).

${ }^{e}$ Construct reliability assumed to be 0.85 .

f Anchored by “'1”' (very small) and “5”' (very large). 